\title{
Use of Fluidized Bed Technology in Solid Waste Management
}

\author{
Doyce Tesoro-Martinez ${ }^{1}$, Tomas U. Ganiron $\mathrm{Jr}^{2}$ and Harold S. Taylor ${ }^{3}$ \\ ${ }^{1}$ Department of Chemical and Materials, University of Auckland, Auckland, NZ \\ ${ }^{2}$ Railway Technical Society of Australasia (RTSA), Wellington, NZ \\ ${ }^{3}$ Department of Computer Engineering, Victoria University of Wellington, NZ \\ 1doycetesoro@gmail.com, ${ }^{2}$ tomasuganironjr@gmail.com, \\ ${ }^{3}$ haroldtaylor1113@gmail.com
}

\begin{abstract}
The use of fluidized-bed for power generation is a rapidly growing technology in Asian countries. Recent development efforts in the world wide energy picture have given much thought to ways of employing fluidized beds in energy conversion and recovery processes, despite stringent environmental legislation concerning waste incineration. This has stimulated the development of advanced combustion, gasification, drying and or cooling of solid particles utilizing the fluidize bed technology The ability of fluidized bed to burn a wide variety of fuels, while meeting strict emission-control regulations, makes them an ideal choice for burning such fuels as high-sulphur coal, lignite, peat, oil, sludge, petroleum coke, gas and wastes. The fluidized bed technology is presented to inform the public about the important applications which can be utilized in dealing with our solid waste disposal problems under environmental restrictions and possible integration of this topic in the power plant design course.
\end{abstract}

Keywords: Fluidization, bed combustion, gasification, metallurgical, fluidized bed technology

\section{Introduction}

The worldwide concern over the constantly increasing cost of oil and gas for energy purposes has brought in recent years a growing need for alternative sources of energy. The use of renewable energy like solar, wind, biomass, and hydro offers a good alternative.

The environmental concerns and the steadily increasing amount of domestic and commercial wastes being produced is one of the pressing problems of our time leading to tight restrictions being placed on the disposal system of Municipal Solid Waste (MSW).

In some well-developed countries like Japan, Switzerland, Denmark and Sweden more than $50 \%$ of municipal solid waste is combusted to generate energy [1]. In these countries, combustion of municipal solid waste is considered to be an efficient and environmentally friendly method of waste disposal and is rising in popularity where energy is recovered.

The applications of fluidized bed technology are presented in the areas of gasification, combustion, drying, and cooling in a fluidized bed which will offer a challenging alternative solution in the future to solve the problems mentioned above meeting the environmental requirements set by the concerned agency [2]. 


\section{Fluidization}

Fluidization is a process similar to liquefaction whereby a granular material is converted from a static solid like state to a dynamic fluid like state [3]. This process occurs when a fluid (liquid or gas) is passed up through the granular material. When a gas flow is introduced through the bottom of a bed of solid particles, it will move upwards through the bed via the empty spaces between the particles.

At low gas velocities, aerodynamic drag on each particle is also low, and thus the bed remains in a fixed state. Increasing the velocity, the aerodynamic drag forces will begin to counteract the gravitational forces, causing the bed to expand in volume as the particles move away from each other [3]. Further increasing the velocity, it will reach a critical value at which the upward drag forces will exactly equal the downward gravitational forces, causing the particles to become suspended within the fluid [3]. At this critical value, the bed is said to be fluidized and will exhibit fluidic behavior. By further increasing gas velocity, the bulk density of the bed will continue to decrease, and its fluidization becomes more violent, until the particles no longer form a bed and are "conveyed" upwards by the gas flow.

When fluidized, a bed of solid particles will behave as a fluid, like a liquid or gas. Like water in a bucket: the bed will conform to the volume of the chamber, its surface remaining perpendicular to gravity; objects with a lower density than the bed density will float on its surface, bobbing up and down if pushed downwards, while objects with a higher density sink to the bottom of the bed [3]. The fluidic behavior allows the particles to be transported like a fluid, channelled through pipes, not requiring mechanical transport.

A simplified every-day-life example of a gas-solid fluidized bed would be a hot-air popcorn popper. The popcorn kernels, all being fairly uniform in size and shape, are suspended in the hot air rising from the bottom chamber. Because of the intense mixing of the particles, akin to that of a boiling liquid, this allows for a uniform temperature of the kernels throughout the chamber, minimizing the amount of burnt popcorn. After popping, the now larger popcorn particles encounter increased aerodynamic drag which pushes them out of the chamber and into a bowl.

\section{Principle of Fluidization}

When a gas is passed through a bed of particles at a steadily increasing rate, a point is eventually reached when the pressure drop across the bed becomes equal to the weight per unit area of the bed, and the bed is then on the point of fluidizing [4]. This critical velocity is termed the minimum fluidizing velocity.

As the gas velocity is increased above this minimum value, there is no corresponding increase in pressure drop across the bed, and the bed expands to permit additional flow. Most of the extra flow passes through the bed in the form of bubbles so that, when the gas velocity is three or five times the minimum fluidization velocity, the system takes on the appearance of a violently boiling liquid $[4,5]$.

In this condition, the bed consists of two regions or phases, the bubble phase and the dense phase, which has a density very close to that of the bed at the minimum fluidizing velocity and through which gas passes interstitially at a flow rate close to the minimum fluidizing velocity. The bubbling action gives rise to high degree of particle mixing in the bed, and because of the large surface area exposed by the particles, thermal equilibrium between gas and particles in the bulk of bed is quickly established as in fluidized bed reactor [5,6]. The solid particles act as a local heat source (or sink) of heat, because of high heat capacity relative to the gas. 


\section{Gasification}

Gasification processes involve heterogeneous gas-solid chemical reactions, which require substantial amounts of heat and mass transfer, and the problems posed in the design and development of plant to carry out these processes have led to a variety of type of gasifiers [7].

Gasifiers are used to produce fuel gas from coal, or other feedstocks such as wood, biomass or refuse. Industrial implementation of gasifiers depends upon the economics of each application and this is affected considerably by the cost of the feedstocks and the efficiency of conversion $[7,8]$.

Fluidized bed gasifiers are one type of gasifier and have advantages of uniform temperature distribution throughout the gasifier and the adaptability to varying load demand without serious loss of efficiency. These gasifiers can be used to produce low sulphur gas content, sufficient to meet environmental requirements, either by addition of limestone or dolomite with the coal feed to absorb the sulphur, or by post-gasification purification techniques.

Figure 1 shows the flow sheet for the fluidized bed gasification plant. It is used for gasifying coal with the presence of limestone [9].

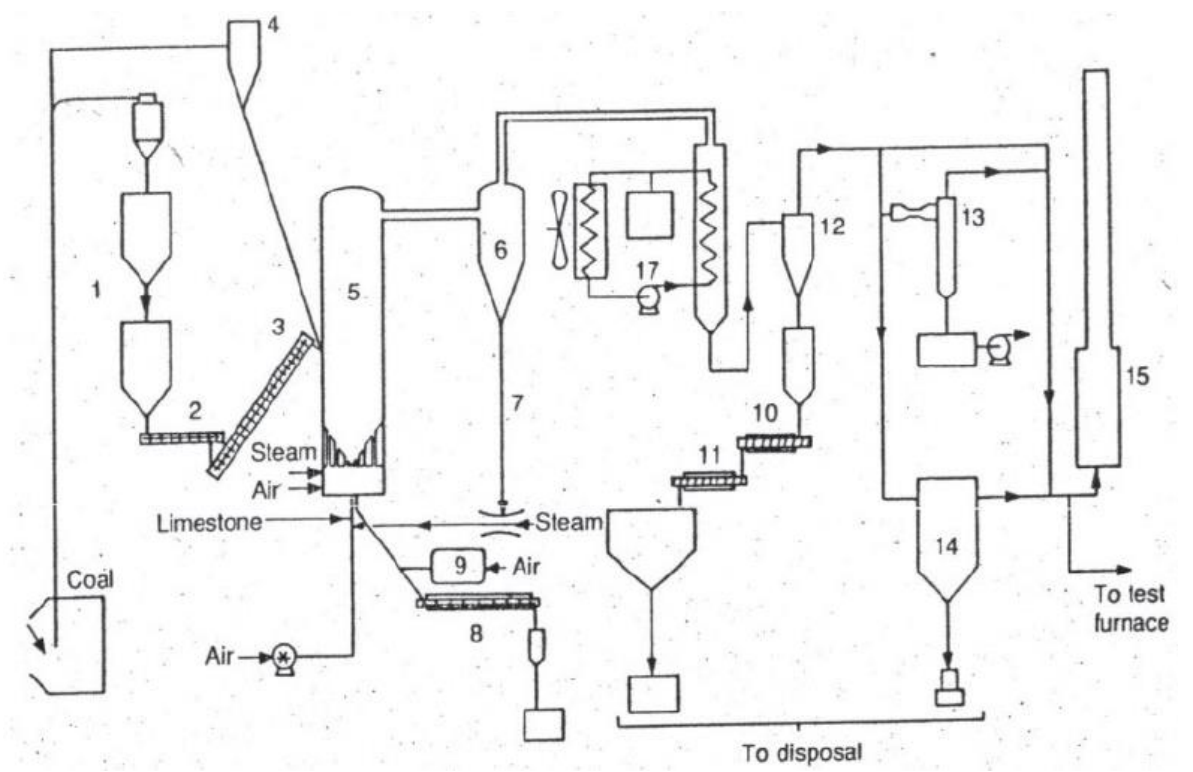

Figure 1. Process flow Diagram for a Gasification Plant Pilot Plant

1)Coal feed lock hopper, 2)Metering screw feeder, 3)Transport screw, 4)Bed feed hopper, 5) Gasifier, 6) Primary cyclone, 7)Fines Recycle leg, 8)Metering Screw feeder, 9) Start-up burner, 10)Fines cooler conveyor, 11) Fines transfer conveyor, 12) Secondary cyclone, 13) Gas Scrubber, 14. Bag filter and 15) Gas flare

Figure 2 shows the Integrated Gasification Combined Cycle (IGCC) for power generation where feed slurry alternatives like coal, heavy oil, petroleum coke, orimulsion, and wastes are used as fuel $[10,12]$. The heart of IGCC technology is gasification, which is an industrial process for the (high in sulphur, heavy metals, nitrogen and heavy organic compounds), in an environmentally benign manner, to a clean burning synthesis gas. This fuel can then be used in advanced technology combined cycle combustion turbines, as well as a feedstock for chemicals production. 
The Texaco Gasification Power Systems process can use almost any solid or liquid hydrocarbon-containing fuels (or mixtures) as feed to the gasification reactor. Feed slurry or fuel mixture is then metered into the gasifier along with a stoichiometric deficient stream of oxygen, thus favoring the production of the partial oxidation products $\left(\mathrm{CO}, \mathrm{H}_{2}, \mathrm{H}_{2} \mathrm{~S}\right)$ over fully oxidized species $\left(\mathrm{CO}_{2}, \mathrm{H}_{2} \mathrm{O}_{2} \mathrm{SO}_{2}\right)$. [11, 12].

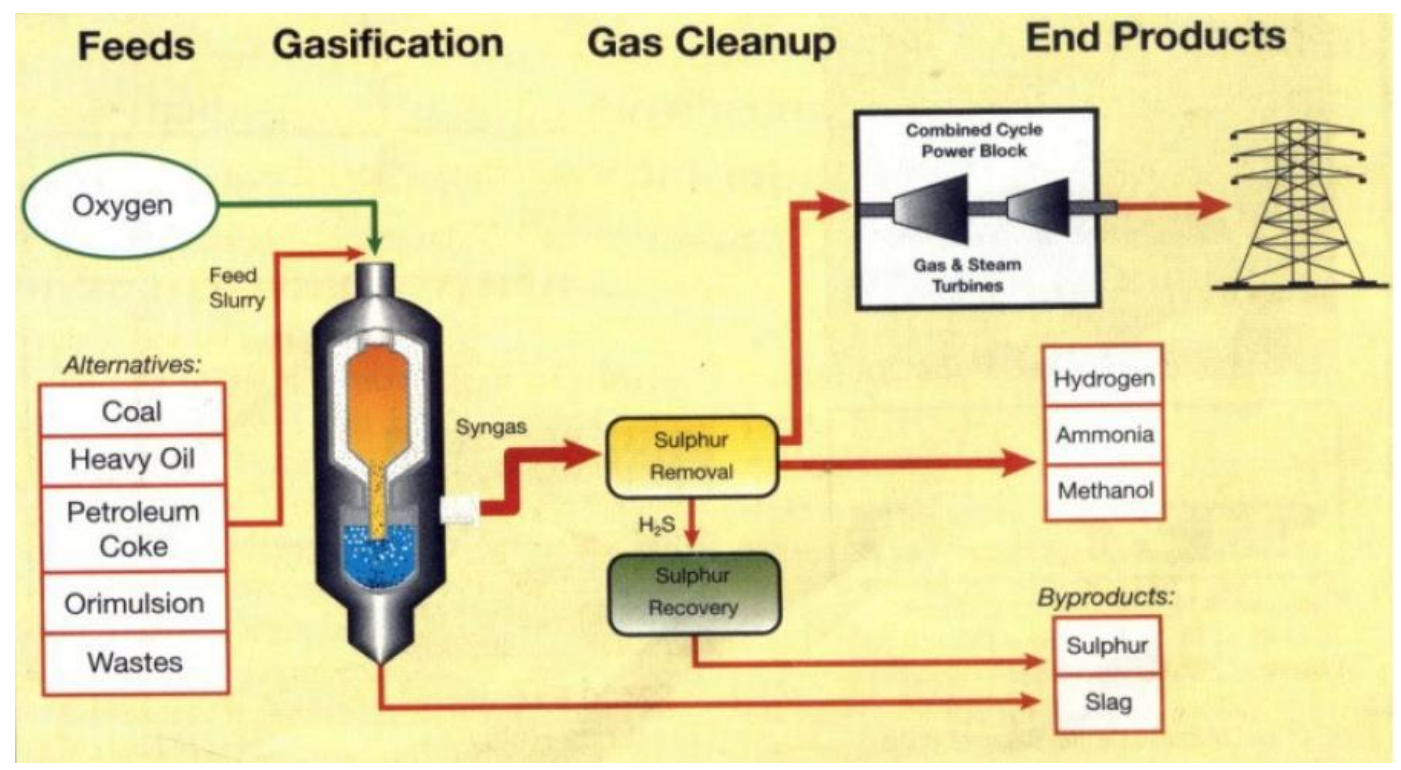

Figure 2. The Texaco Gasification Process

\section{Combustion}

In power plants, modern technology reduces sulphur dioxide, nitrogen oxide and dust content in flue or stack gases. One particular method still used on a relatively small scale and in different configurations. But in other developed countries like Japan, Switzerland, Denmark and Sweden, bigger installations are existing generating energy from waste in a fluidized bed.

\section{Fluidized Bed Combustion (Waste to Energy)}

Figure 3 shows the Spain's Sogama waste to energy facility process diagram. The Sogama plant will process approximately 650,000 tons of MSW into 400,000 tons of Refuse Derived Fuel (RDF) each year [13]. The plant consists of four major parts. Municipal Solid Waste (MSW) is delivered by rail from transfer stations, the materials recovery facility, the boiler island, the turbine island, and the cogeneration plant $[13,15]$.

MSW is fed into trammel, which separates small and large particles. The waste is dried by hot gases from the cogeneration plant and valuable material recovered for recycling. The remaining material is shredded and conveyed to the boilers. Recycled material will include glass, paper, iron, aluminum, plastics, and cardboard.

A boiler island incorporating two $75 \mathrm{MW}$ and Circulating Fluidized Bed (CFB) boilers, a dry flue gas cleaning system and a bag house filter. This section accounts for one third of the total cost of the plant [14]. 
A turbine island consists of two steam turbines driven by steam from the two boilers. A total of 49MW of electricity is generated for export to the local grid. Cooling is provided by a water-cooled condenser and a cooling tower.

A cogeneration plant is based on four gas engines, generating 21.6 MW of electricity and hot flue gas at $385^{\circ} \mathrm{C}$ used for drying MSW [15].

The fuel chute is equipped with high velocity air nozzles that will spread the fuel evenly over the cross-section of the furnace in order to achieve a homogenous and complete combustion, leading to low emissions of $\mathrm{NO}_{\mathrm{x}}, \mathrm{CO}$ and organic compounds.

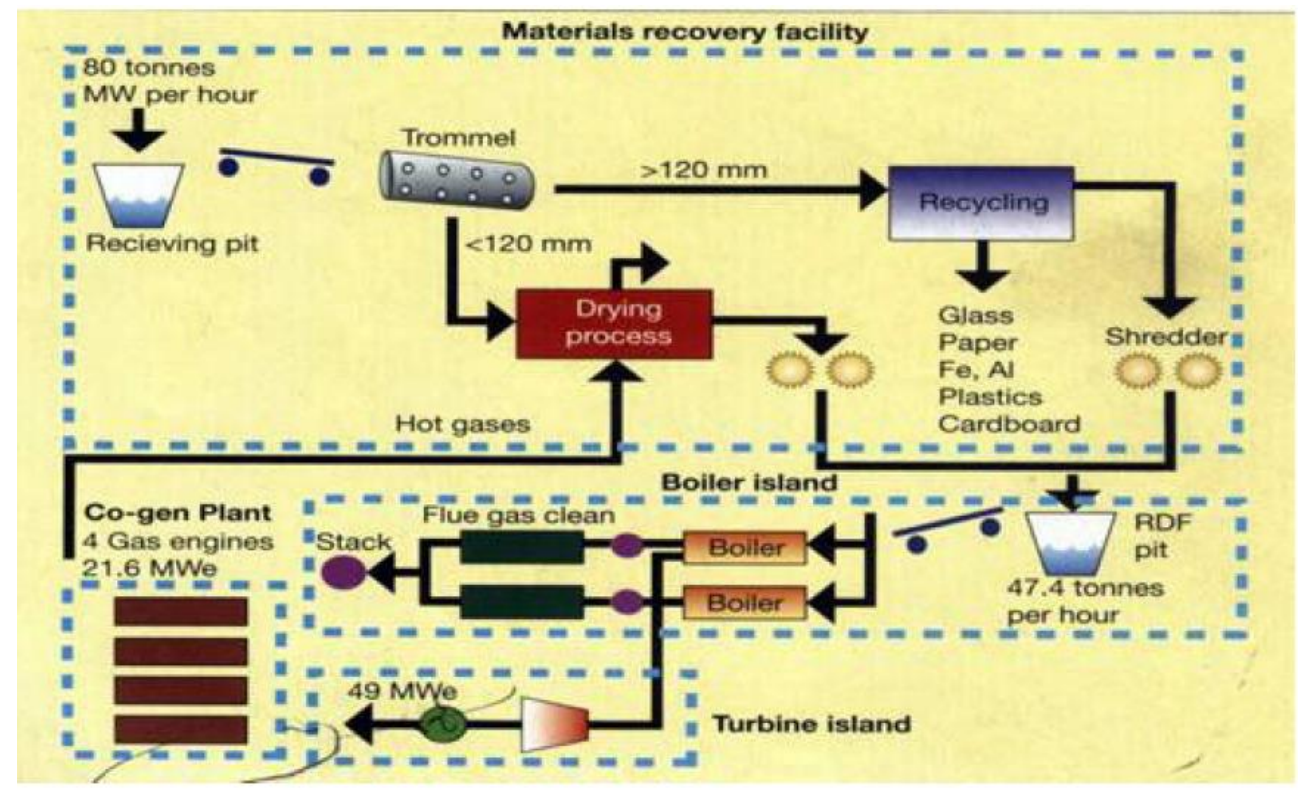

Figure 3. Sogama Waste to Energy Facility Process Diagram

\section{Dryers}

Moist substances may be dried by passing hot, dry gases through the damp material. Whether or not the material to be dried is fluidizable, a supply of hot relatively dry gas is needed. In some cases, the product to be dried will tolerate being dried by hot gases from combustion processes, whereas other products are less tolerant and require uncontaminated gas such as clean hot air.

Fluidized bed furnaces have been developed as hot gas generators for crop drying, cement manufacture, drying and or cooling of sugar in the fluidized bed [16]

\section{Drying and Coling}

In Figure 4, BMA fluidized bed dryer shows the drying and /or cooling of sugar in a fluidized bed [17]. Fluidization of the sugar crystals enables almost the total product surface to become the contact surface for the drying and cooling air [17, 18]. This results in an intense heat and mass transfer, providing for an extremely efficient removal of surface moisture and product heat. 


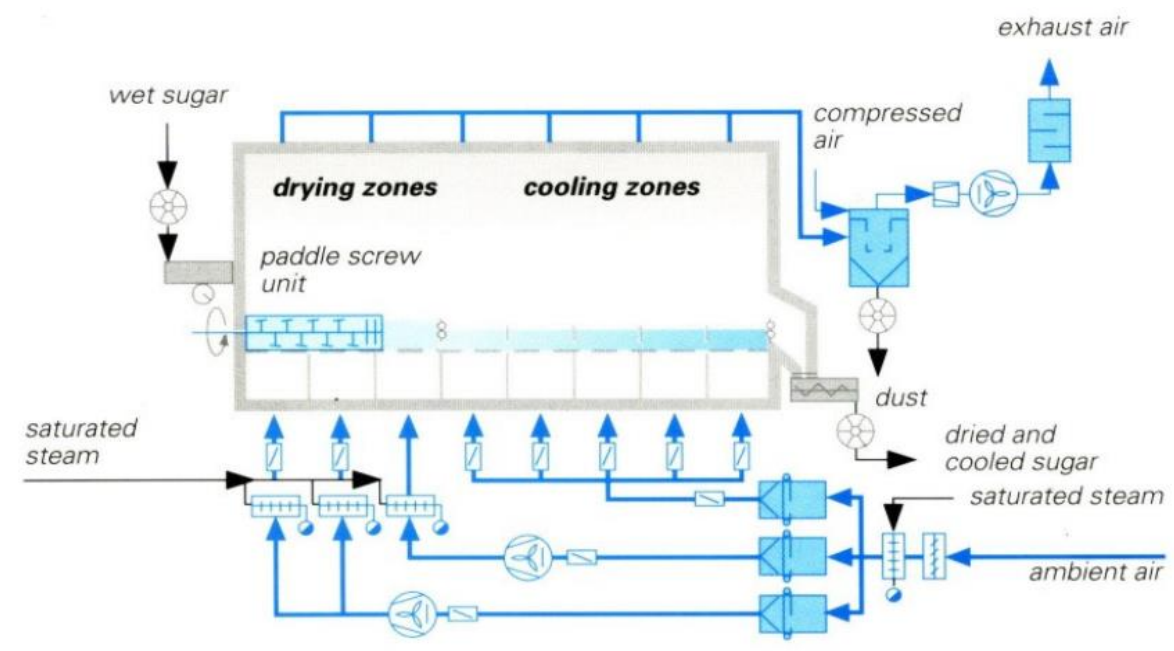

Figure 4. Fluidized Bed Dryer / Cooler System

\section{Metallurgical Heat Treatment}

Gas fired fluidized bed furnaces used for the heat treatment of metals, notably for hardening and tempering [19]. In [19, 20] also used fluidized bed furnaces for quenching.

Fluidized bed furnaces have been developed to include surface treatments including carburizing, nitriding and steam tempering. Conditions for carrying out the boost/diffuse technique used for carburizing in a conventional carburizing furnace can be improved when performed in a fluidized bed heat treatment furnace [20]. This improved boost/ diffuse carburizing cycle leads itself to accurate mathematical modeling, which enables both process simulation and on-line computer optimized control to be exploited. Other references to fluidized bed furnaces include [20-22]

\section{Solid Transport Systems}

Solids transport within the fluidized systems and from point to point are important to several processes and the reliability of the system. Fluidization based techniques can often offer the best solution to solids transport problem.

In [23] has given an account of the state of the art of transporting solids by fluidized techniques and controlling their flow.

In addition to solids conveys system such as dense or dilute phase pneumatic transport systems, standpipes, etc. Non mechanical valves, which have no moving parts and are cheap, can be used to control or feed solids into equipment as fluidized beds, or solids conveying systems.

\section{Flue Gas Desulphurization}

The desulphurizing of flue gases from a purer solution fired by sulphurous coal is best described by [22]. It incorporates the circulating fluidized bed technique. Flue gases preferably with entrained solid separated from it, enter a venturi reactor. These solids are mixed with fine particles of hydrated line injected into the reactor which, because of the intimate gas/particle contact absorb sulphur readily [24]. These particles are carried out of the reactor because the gas velocity is high and are then captured by a dust separator and recirculated back to the venturi reactor many times to give a very long residence time. 


\section{Fluidized Bed Catalytic Cracking}

Catalytic cracking is the process used for converting heavy oils into gasoline and other valuable products. Figure 5 shows the essence of the process [25].

Hot fine catalyst particles $\left(70 \mathrm{~m}\right.$.) at temperatures in the region $\left(650^{\circ} \mathrm{C}-750^{\circ} \mathrm{C}\right)$ are injected into the hot oil feed to a fluidized bed reactor at the base of a riser feeding to the reactor [25], [28]. Vaporization occurs and the mixture of hot vapour and entrained catalyst is lifted to the reactor, reacting endothermic ally. Most of the catalytic reaction occurs in the riser during the transport. The reactor serves mainly to separate the catalyst from the hydrocarbon vapour.

After disengagement from the catalyst the hot, cracked hydrocarbon vapours are transported for further processing. The separated catalyst particles are heavily coked and transported to the regenerator via a steam-stripping zone.

The coked catalyst passes to the regenerator, whose main purpose is to oxidize the coke on the catalyst and re-expose the catalyst surface ready for reuse in the catalytic cracking reactor $[26,27]$.

Oxidation of the coke on the surface liberates heat, raising the temperature of the catalyst particles ready for re-injection into the hot oil feed to the reactor.

Combustion products and certain amount of entrained catalyst are conveyed upward from the surface of the dense-phase fluidized bed in the regenerator and captured by cyclones inside the regenerator and retain to the bed [27]. The cleaned combustion products then leave the regenerator for further cleaning and heat recovery from the hot combustion products.

The reactor and regenerator constitute two fluidized systems which exchange solids continuously by fluidized transport systems. Large amount of heat and mass are therefore being transferred.

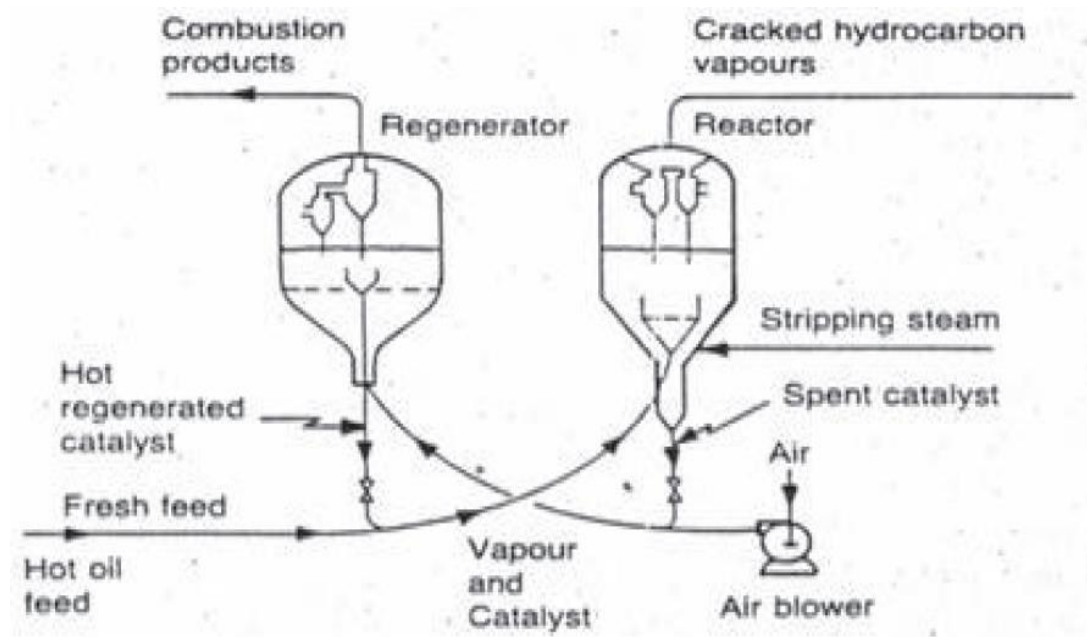

Figure 5. The Essentials of a Catalytic Cracking Plant

\section{Conclusion}

Fluidized bed technology has developed largely from experimentation. The design of fluidized plant is likely to continue and gain the favour to be something of an art and rely considerably upon observed behavior and data obtained from previously constructed plant or pilot plant. If fluidized bed combustion is successful in general use, a new impetus could be given to fossil fuel use, even of such low quality as heavy oil, used oil and municipal solid waste, but also coal. 
Fluidized bed technology applications have gone far beyond combustion, gasification, catalytic cracking, heat treatment furnaces, solids transport but also effective in drying or cooling moist substances where clean hot air and ambient air are the fluidizing medium.

So far as a fluidized bed itself is concerned, a good design of the distributor is probably the first requirement because of the importance of uniform distribution of the fluidizing gas into the bed.

As with any other branch of technology, successful exploitation requires that the technology is not only timely, but that it should also incorporate good design and operating practice thus meeting the environmental standards. However, underlying principles have evolved gradually through experience.

\section{References}

[1] P. Basu and S. A. Fraser, "Circulating Fluidized Bed Boiler, Butterworthh-Heineman, (1994).

[2] W. M. Gao, L. X. Kong and P. D. Hodgson, "Numerical Simulation of Heat and Mass Transfer in Fluidized Bed Heat Treatment Furnaces", Journal of Materials Processing Technology, vol. 125, (1997), pp. 170-178.

[3] R. Krishna, J. Ellenberger and D. E. Hennephof, "Analogous Description of the Hydrodynamics of Gas-Solid Fluidized Beds and Bubble Columns", Chemical Engineering Journal and the Biochemical Engineering Journal, vol. 53.1 (1993), pp. 89-101.

[4] T. U. Ganiron Jr, "Fluid Mechanics Laboratory Manual", Victoneta Press, Far East Air Transport Incorporated University, Manila, (1997).

[5] J. R. Grace, C. J. Lim and J. Chaouki, "Circulating Fluidized Bed Reactor Design and Operation", Sadhana, vol. 10, no. 1, (1987), pp. 35-48.

[6] J. F. Davidson and D. L. Keairns, "Fluidization", Proceedings of the Second Engineering Foundation Conference, Trinity College, Cambridge University , (1978) April 2-6.

[7] J. S. Botterill, "Fluidized Bed Behaviour", Fluidized Beds: Combustion and Applications, JR Howard, (1983), pp. 1-36.

[8] T. M. Knowlton and D. Geldart, "Gas Fluidization Technology", Wiles \& Sons, New York, pp. 341, (1987).

[9] F. Cavalleri, G. F. Tosi and P. L. Cavallotti, "Nitriding of Sintered Steels and Nitro carburizing of Steels in Fluidized Bed Furnace”, Materials Science Forum, vol. 102, (1992) January 2, pp. 249-258.

[10] T. U. Ganiron Jr, "Hydraulics Laboratory Manual", Victoneta Press, Far East Air Transport Incorporated University, Manila, (1994).

[11] Z. Gawrzynski and R. Glaser, "Drying in a Pulsed-Fluid Bed with Relocated Gas Stream", Drying Technology, vol. 14.5, (1996), pp. 1121-1172.

[12] H. Vogg, M. Metzger and L. Stieglitz, "Recent Findings on the Formation and Decomposition of PCDD/PCDF in Municipal Solid Waste Incineration", Waste Management \& Research, vol. 5.3, (1987), pp. 285-294.

[13] J. K. Seadon, "Integrated Waste Management-Looking Beyond the Solid Waste Horizon", Waste Management, vol. 26, no. 12, (1987), pp. 1327-1336.

[14] T. U. Ganiron Jr, R. Sison, H. Tomagos, F. Polanco, C. Imbien, J. Keng, M. Henson and W. B. Chaundry, "A Study of Hydroelectric Dam as a Solution to the energy Crisis in Angat Bulacan”, BS Thesis, Civil Engineering Department, FEATI University, Manila, (1999).

[15] A. A. Boateng, D. Daugaard, N. Goldberg and K. Hicks, "Bench-Scale Fluidized-Bed Pyrolysis of Switch Grass for Bio-Oil Production”, Industrial \& Engineering Chemistry Research, vol. 46.7, (1997), pp. 18911897.

[16] Y. Yang, Y. Liu and A. Squires, "Pressure Drop across Sallow Fluidized Beds: Theory and Experiment", Powder Technology, vol. 53.2, (1987), pp. 79-89.

[17] H. Hattori and J. Howard, "Gas-to-Gas Heat Recovery using Fluidized Bed Technology", Journal of Heat Recovery Systems, vol. 5, no. 6, (1987), pp. 535-544.

[18] T. U. Ganiron Jr, M. Pillas, J. Masa, A. J. Reyes and A. Caporal, "Efficiency of Rubber Gate in Bustos, Bulacan", BS Thesis, Civil Engineering Department, FEATI University, Manila, (2001).

[19] J. Jung and D. Gidaspow, "Fluidization of Nano-Size Particles", Journal of Nanoparticle Research, vol. 4, no. 6, (2002), pp. 483-49.

[20] J. Corella, J. M. Toledo and G. Molina, "A Review on Dual Fluidized-Bed Biomass Gasifiers", Industrial \& Engineering Chemistry Research, vol. 46, no. 21, (2007), pp. 6831-6839.

[21] E. Rivera, C. Ronco and N. Lucenada II, "Efficiency of Wastewater Treatment of the Pandacan Oil Depots", BS Thesis, Civil Engineering Department, FEATI University, Manila, (2003). 
[22] E. Anthony and D. Granatstein, "Sulfation Phenomena in Fluidized Bed Combustion Systems", Progress in Energy and Combustion Science, vol. 27, no. 2, (2002), pp. 215-236.

[23] J. Eje, E. Estavillo, A. Laguatan and M. A. Mumtaz, "Water Distribution System on Subdivision of Southville, Molino Bacoor, Cavite”, BS Thesis, Civil Engineering Department, FEATI University, Manila, (1997).

[24] Y. Li and M. Kwauk, “The dynamics of Fast Fluidization”, Fluidization, Springer US, (1980), pp. 537-544.

[25] T. U. Ganiron Jr, E. D. Castro, J. D.Vera, M. Potolin and R. Balmadres, "Reinforced Concrete Pipe Culvert", BS Thesis, Civil Engineering Department, FEATI University, Manila, (1997).

[26] C. Wen and Y. H. Yu, "Mechanics of Fluidization", Chemical Engineering Program Symposium, vol. 62, no. $62,(\mathbf{2 0 1 3})$.

[27] R. Nichols, J. Sparks and C. J. N. Wilson, "Experimental Studies of the Fluidization of Layered Sediments and the Formation of Fluid Escape Structures", Sedimentology, vol. 41, no. 2, (1994), pp. 233-253.

[28] M. Ye, M. A. Van der Hoof and J. A. M. Kuiper's, "A Numerical study of Fluidization Behavior of Geldart: A Particles using a Discrete Particle Model”, Powder Technology, (2002), pp. 139.2, pp. 129-139.

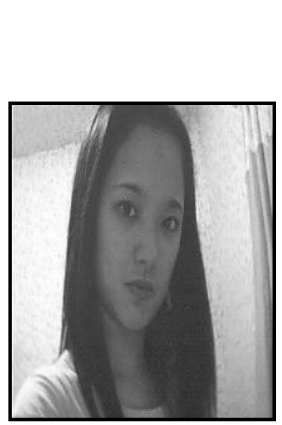

\section{Authors}

Doyce Tesoro-Martinez was born in San Fernando, La Union. She received both BS and MS Chemical Engineering from De La Salle University, Manila in 2000. Ms. Tesoro-Martinez has been pursuing research in fluidized web technology and waste treatment plant, She has published over 30 referred papers in relevant journals and conferences, which majority focus on the areas of manufacturing engineering and efluidized.

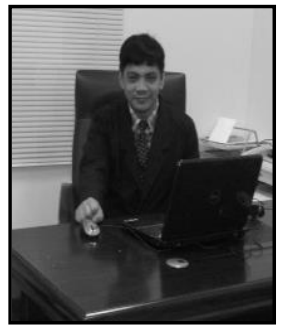

Tomas U. Ganiron Jr., this author obtained his Doctor of Philosophy in Construction Management at Adamson University (Philippines) in 2006, and subsequently earned his Master of Civil Engineering major in Highway and Transportation Engineering at Dela Salle UniversityManila (Philippines) in 1997 and received Bachelor of Science in Civil Engineering major in Structural Engineering at University of the East (Philippines) in 1990. He is a registered Civil Engineer in the Philippines and Professional Engineer in New Zealand. He has received the Outstanding Civil Engineer in the field of Education given by the Philippine Media Association Inc. (1996), ASTM Award CA Hogentogler (2008) by IPENZ in New Zealand and Outstanding Researcher (2013) in Qassim University, Buraidah City.

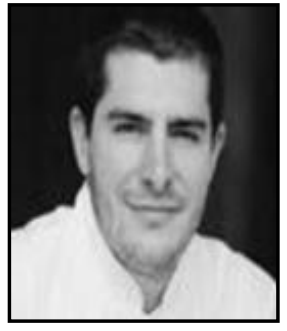

Harold S. Taylor received the BS Civil Engineering degree at University Canterbury in 1983 and earned his MS (1985) and PhD (1987) degrees in Civil Engineering at University of Auckland. He has published several research papers in national and international journals in the area of hydrology, water resources engineering, waste treatment plant and river engineering. He has also authored books viz, Ocean Engineering, River and Sediments, Water Resources and Engineering, and Fluid Mechanics Students' Handbook. 
International Journal of $u$ - and e- Service, Science and Technology Vol.7, No.1 (2014) 